Covered in: ERIH PLUS, HeinOnline, CEEOL, Index Copernicus, CrossRef, CrossCheck, J-GATE, Google Scholar, Ideas RePeC, Econpapers, Socionet, KVK, WorldCat.

\section{Perspectives on the Right to Establish Economic Activities in the Field of the European Community}

\section{Daniela LAMEŞ1}

${ }^{1} \mathrm{PhD}$, Arbitrator, Permanent Court of Institutionalized Arbitration, Romania, lamesdaniela@yahoo.com

\begin{abstract}
Accession to the European Union has led to the existence of a common market, the need for regulations of state, regional and community legal norms regarding the establishment of economic activities and liberal professions in the European Union. These have led to unitary regulations in the system of Community law. The study presents the characteristics and the benefits that the economic agents acquire through the economic activity carried out, with the beneficiary being the third party. This is confirmed by law, rights and limitations, so in the context of the presentation, we present the conditions and principles underlying any economic agent: non-discrimination, free access to the single market, equivalence of study documents, etc. We present the normative classification regarding the activity of the economic agents, the updating of the Romanian legislation to the European regulations, notices and directives, which lead to their implementation in Romania by transposition into the Romanian legislation. The present study outlines the right of citizens to have a place of business in the territory of another Member State of the European Union. As a novelty, we are configuring the progress made on the right of establishment of economic agents, noting the substantive and procedural aspects applied to nationals as direct beneficiaries of the economic activities in the European Union.
\end{abstract}

Keywords: third party; community; legal offices; treaty; regulation; professions; economic agent; legal norm.

How to cite: Lameş, D. (2019). Perspectives on the Right to Establish Economic Activities in the Field of the European Community. Logos Universality Mentality Education Novelty: Law, 7(1), 26-35. doi:10.18662/lumenlaw/15 



\section{Introduction}

The European Union has set up a common market with a legal system based on normative recommendations. The system gives a uniform nuance both from the point of view of the comparative law in the Member States and as a main object in the development of the common market.

Each Member State of the European Union can be ranked in different stages depending on its membership of the Union. Citizens have different rights and obligations depending on the state of the labor market at the time of accession.

By addressing the defining component, the right of establishment, according to the case-law of the European Court of Justice, is "the right of a national to participate, in a stable and continuous way, in the economic life of a Member State other than his or her State of origin obtains income from a non-social activity" (CJCE, Gebhard, 1995).

\section{Resortisantul}

The national may be a natural or legal person, which belongs to a State but carries on business in the territory of another State. Establishing the professional activity of a national focuses on the establishment of a principal or secondary establishment in conjunction with permanent establishment in the receiving State. The activity will be done in the economic sphere. The limitation is to exclude activities in the field of public authorities in the receiving State.

The principles of establishing economic agents in the European Union consist of discriminatory measures regarding nationality and assimilation of citizens.

\section{The community legal system}

The Community legal system includes the provisions of the Treaties of the European Union implemented in the laws of its Member States by Directives. The directives' regulations relate to certain professions or economic activities implemented in the legislative system of the Member States. They aim at normative normalization within the community that leads to progress, systematization of professional activities, solving in fact and basically all situations that are not in line with reality.

In view of the accession of Romania to the European Union, we will bighlight the treaties, agreements and conventions that were the basis for the implementation of the right of establishment of the Romanian citizens in the Romanian legislation. 
The normative acts highlight the dynamics of the development within the European Community of the right to pursue, both as a selfemployed person and as an economic activity, by legal persons who carry out a gainful activity in the territory of a state other than that of whose citizenship they hold.

The right of establishment was regulated in the European Community between 1992 and 2001 by the Treaty of Rome art. 52 - art. 57 (the Treaty of Rome, 1998, article 52 - article 57) a normative act stating the free movement of persons, services and capital.

The Maastricht Treaty provides for provisions on determining the Council in a decisive activity (the Maastricht Treaty, 1952, procedure 189 B).

Also, by the Treaty on the European Economic Area (Treaty on the European Economic Area, 1992, in force since January 1, 1994), nationals are free to establish themselves in a Member State of the European Community or a State of the European Association of Free Trade on the territory of another state is part of one of them (EFTA).

The movement of workers, the right of establishment and the provision of services are regulated by the Convention of the Association of Romania to the European Union in art. 45 - art. 55. (Romanian Association Convention, articles 45-55).

By the Treaty of Nice on 26 February 2001 amendments were made to the Treaty of the European Union and other related acts which, by the decision to enlarge the European Union, are stipulated in Art. 47 paragraph 2 of the EC Treaty that it will be necessary for all states to vote on access to and the exercise of non-salaried professions (Tinca, 2001).

Since March 2000, the Lisbon European Council has been adopting a reform program in the European Union by 2010 on the dynamic development of the economy, which has as an essential attribute the competitiveness between states. (European Council in Lisbon, 2000).

In 2006, on 5 September, professional services bring to the forefront the European Commission the recognition of the contribution that the liberal professions in the Member States bring to the labor market of the European Economic Community with the aim of reforming them.

Directive 2013/55/EU specifies the rules on the professional qualifications of the receiving State in the case of cross-border professional assistance. Ethical and practical standards have been developed for incoming country professionals and codes of conduct for outstanding individual professions.

At Community level through Directive no. 2006/123 / EC, codes of conduct for services in the Internal Market of Member States are developed, 
in cooperation with the European Commission, that address the accessibility of economic resources.

\section{The Role of European Code of Conduct}

The role of European Code of Conduct and the improvement of service quality within the Internal Market are highlighted in 2007 through the European Commission's Report. The report highlights: regulating professions by guaranteeing their exercise. The impartiality of the rules of professional conduct emphasizes the specific nature of the sectors of activity and services.

Due to the integration of new states in the European Union, both the frequency of cross-border activities and the number of members in the European Union are increasing. The accession of new states has a major impact on the evolution of professional practice within the European Liberal Professions Council.

Differences in the values of each Member State arise in this context. These are reflected in the codes of each country, according to the specific legal rules and the provisions of the individual professional codes.

The common values established by the two Directives and the European Liberal Arts Council report are based on principles such as confidentiality, participation in professional development, independence and impartiality, conflicts of interest, honesty and integrity, supervision of support staff, compliance with codes of conduct, professional liability, conflict with moral or religious beliefs, dispute resolution, reporting obligations, training in ethical standards and good governance, etc.

\section{The Role of Liberal Professions}

The role of liberal professions in the perspective of civil society up to 2020 is set out in the notice created on 14.02.2013. These are found in the contents of art. 29 par. (2) on the Rules of Procedure of the European Economic and Social Committee.

The recommendations of this document embody the liberal profession from an economic point of view, taking into account the present and future requirements of the liberal professions, taking into account the protection of consumers and the autonomy of the services offered.

In the context of the free movement of workers, Directive 2014/54 / EU of 16 April 2016 issued by the European Parliament provides workers with facilitation measures and the exercise of rights deriving from their professions and activities. 
Romania transposes these regulations by Law no. 156 of 2000 which contains provisions regarding the protection of Romanian citizens domiciled in Romania who work abroad. The provisions of the aforementioned normative act regulate: - the conditions of operation and the registration procedure of legal entities who operate on the territory of Romania and work abroad; - informing, advising and mediating the Romanian citizens in hiring staff through placement services abroad.

The Romanian legislature establishes the conditions for the protection of Romanian citizens with the status of nationals by art. 3 of Law no. 156/2000. Through this normative document, the Government of Romania has the power to conclude agreements, understandings, treaties or conventions with similar public authorities in the Member States with regard to: respecting equal treatment, minimum wage, working time and rest, general working conditions, labor insurance and accidents (Law 156/2000).

Regarding the protection of Romanian citizens working abroad by Law no. 232 of November 29, 2017, amendments and additions are made, clearly emphasizing the role of work placement, regarding: the regulation of the placement activity and the activities carried out in connection with : Mediation, Interpolation, Job Service Provider or other categories of intermediaries.

Through the amendments and additions to the Law no. 232/2017 during the engagement of the Romanian citizen, the laws of the receiving state, the bilateral agreements, agreements and conventions between Romania and the receiving state, as well as the stipulations stipulated in the labor contract will be respected.

These provisions increase the safety of the citizen through the rights under both the legal rules and the contract concluded to safely carry out activities within the European Union.

Analyzing the freedoms discussed in the rules, directives and provisions above, we note that the right of establishment is distinct from the freedom to provide services. The EC Treaty provides for these freedoms to be equal, it follows from the provisions of this normative act that there is no possibility of choosing between them.

The establishment regime provides for the freedom to provide services to apply the internal rules of the States concerned. Specific situations consist of economic activities throughout the Community.

Delivering liberalization of services and free movement of citizens at the beginning is progressing slowly, but the evolution of the debated issue has a dynamic aspect through the diversity and the multitude of situations that have arisen within the EU. 
The Community thus adopts provisions regulated by the Member States with a view to achieving a common legal regime in the European Single Market.

\section{Beneficiaries of the Right of Establishment}

Beneficiaries of the right of establishment are natural and legal persons. If we have mentioned that the nationality belongs to the national criterion and their right to settle in another EU state, we mention the legal persons according to the provisions of art. 58 of the Treaty on the European Economic Area that they are assimilated to nationals, companies irrespective of their legal form if they pursue a lucrative purpose, if they are constituted under the law of a Member State or have their principal place of business in the EU.

Performing a professional activity in member countries may be a self-employed or a liberal profession. Freedom of establishment also covers the establishment, management of individual undertakings or commercial companies.

The requirement for legal persons to establish their place of business depends on their legal relationship with the Member States and on the free movement of holders and not on their nationality as long as the shareholder holds the citizenship of one of the EU Member States.

The establishment of legal persons in a State other than that of which they hold a nationality may be permanently in the form of a principal place of business or as a secondary establishment.

Relevant, we consider to be the case in European Community jurisprudence, where the permanent presence of legal persons is recognized by its Court of Justice in GEBHARD v / Council of the Milan Lawyers and Prosecutors' Council in case C55 / 1994. By the right of establishment, the permanent presence of a business in a Member State, even if it has not been legally constituted in a branch, subsidiary, agency, etc., is considered as a defining element. (CJCE - Case C55 / 1994).

\section{The Secondary Establishment of Legal Person's}

The secondary establishment of the legal person's registered office is in two forms. The two modes of existence of an independent enterprise are: the taking over, the transfer, the creation, the establishment, the purchase or the management of an enterprise, and the second the formation of an enterprise. 
Establishment of legal entities in the form of secondary offices. In this case, there are undertakings with headquarters in a Member State and in the territory of another Member State of the European Community they own branches which do not have legal personality, having only their own autonomy and subsidiaries, legal personality, they are autonomous, the economic view is dependent on the headquarters of the open society. Secondary offices also have the legal form of foundation or association that carries out economic activity.

The three forms of establishment of nationals: permanent, primary and secondary, have as a consequence the settlement of a Community legal order. The effect is to implement them in the national law system through internal normative acts in the Member States.

Moving from the economic activity of commercial companies, associations and foundations to the activities permitted by the right of establishment of nationals, we have as a restrictive criterion the exercise of liberal professions on the basis of possession of a diploma or professional qualification recognized by the state on whose territory the national is carrying out activity.

Through the Reyners judgment of 21.06.1074, the Court of Justice of the European Community regulates the professional status of the holder of a lawyer issued by Belgium. The Court states that the applicant is required to enter the regulated profession in the receiving State.

Nowadays, thanks to the Treaties and the Directives concluded between states, important steps have been taken in the normalization of the norms stipulating how the liberal professions can take place in law and in fact throughout the European Union.

Community law, through the development of codes of ethics, aims to integrate continuously into the European Economic Space, cross-border enhancement and the elaboration of rules applicable to each liberation profession.

An example of this is: Directive 77/249 / EEC and Directive 98/5 / EC. These are based on the deontological code of lawyers in the European Union. It was originally adopted in the plenary session of 28 October 1988 and subsequently amended in the CCBE Plenary Sessions of 28 November 1998, 6 December 2002 and 19 May 2006.

Freedom to provide services can in principle be corroborated with the free movement of goods, capital and the provision of services. 


\section{Establishing tax rules}

Establishing tax rules is the interdependence between the tax rules transposed into national legislation so as to avoid double taxation.

In order to have a fair, efficient and favorable system in the EU, the value of the taxes and taxes is paid by every citizen determined by the government of the country of origin of the citizen. If the activity carried out by a national is on the territory of the receiving State, taxes will be payable in the country where the natural or legal person has its tax domicile. The aim is to coordinate economic policies, tax systems and income earned from activities within the Community Economic Area.

Thus, the European Commission estimates in line with the Directives tax issues on: direct taxation of citizens and indirect taxation. Direct taxation has as its scope the exclusive competence of the Member States, while indirect taxation concerns the coordination and harmonization of value added tax and excise duties.

The effect of tax harmonization allows nationals to avoid double taxation, to prevent involuntary non-taxation and tax evasion, to capitalize on the benefits of a single market and to reduce the compliance costs of non-residents' compliance with the provisions of several tax systems.

\section{Conclusions}

Currently, we note that there is no fully integrated European fiscal system, which is why every tax regulatory decision is individually transposed at the level of each Member State. It is an effort both from the Member States and at the decision-making level of the European Community, but it avoids the asymmetric tax shocks within it, avoiding fiscal and economic imbalances.

The context of the European space provides citizens with the freedom and security of the conduct of their economic activities. In order to manage the migration of the citizens of the Member States from one region to another or from one Member State to another, the decision-making coherence within the European Union area is important. But this is not enough, it is necessary to implement the European Directives in the legislation of the member states in order to achieve and ensure national policies for each economic-fiscal field.

As far as the field of activity of natural or legal persons is concerned, namely, liberal professions, things have been outlined lately by codes of ethics for each liberal profession. 
As a novelty, we consider it appropriate to issue and implement at state level in most liberal professions the implementation and development of these codes of ethics for a wide range of liberal professions. It is taken into account that nationals carrying out unrecognized liberal professions at the level of the European Community have a difficult way to go by recognizing the diploma or qualification of the person concerned.

This recognition process is disadvantageous in time, recognition of the receiving state qualifications, and support for access examinations in the profession or registration in a particular professional organization.

We propose the establishment of a European Job Catalog. A nomenclature to hold all liberal professions in the U.E. It is understood that on the basis of such a nomenclature it is necessary for all liberal professions to issue codes of ethics to be transposed by provisions and their implementation at the level of each member state. I have now observed that not all liberal professions have clear regulation through Community provisions and codes.

If a Member State does not regulate a particular liberal profession, the necessary steps should be taken to carry out regulatory and professional organization so that the unity of the liberal professions at European level is consistent with the recognition and implementation of the provisions of the codes of ethics in each Member State.

We appreciate that economic activity concerns enterprises that belong to a Member State but operate in another country. I mentioned the second possibility when the person belonging to a particular Member State is the economic activity as a legal person in another Member State of the European Union. The two modalities produce tax effects, regulated by E.U. By transposing them into the laws of the Member States, a number of elements such as double taxation are avoided.

In conclusion, although there is visible progress in regulating the right to carry out economic activities throughout the European Community, nationals who carry out economic activities still encounter situations where certain economic activities and liberal professions do not fall within a unitary regulation of all Member States.

The novelty consists in proposing a nomenclature which includes all the liberal professions in the European Community. But also to the right of establishment of European Union economic operators without further procedures. Thus, the paper highlights the situation of nationals carrying out economic activities by: integrating from the point of view of the normative provisions transposed from the European level to the individual Member 
States, thus eliminating fiscal, economic and of the free movement of goods and persons.

\section{References}

CJCE, Reyners judgment of 21.06.1074, 1974 Collection of Decisions, p. 631;

Directive 77/249 / EEC, Directive facilitating the effective exercise of the freedom to provide services by lawyers, Council Directive of 22 March 1977

Directive 98/5 / EC, the permanent pursuit of the profession of lawyer in another EU country than the country in which the qualification was obtained, to the European Parliament and the Council on 16 February 1998.

ECJ - Gebhard judgment of 30.11.1995, Case C-55/94, Reports of Judgments, 1995, pp. 41-65;

Extraordinary European Council in Lisbon, 23-24 March 2000 and renewed by the Brussels European Council of 22-23 March 2005. Retrieved from http://vechi.anpcdefp.ro/userfiles/Anexa 3 TiM Strategia Europa 2020 .pdf

Law no. 156/2000 of 26 July 2000 *** The Republic of Romania on the Protection of Romanian Citizens Working Abroad, republished in the Official Gazette of Romania, Part I, no. 291 of May 5, 2009;

The Association of Romania to the European Union, February 1, 1993.

The European Free Trade Association was established in 1960 (EFTA).

The Maastricht Treaty, also called the Treaty of the European Union, signed on 7 February 1992, in force on 1 January 1993, procedure 189 B.

The Treaty establishing the European Economic Community (EEC) was signed in Rome on 25 March 1957 and entered into force on 1 January 1958, 52 art. 57.

Tinca, O. (2001). Treaty of Nice. Law Magazine, 9/2001, p. 14.

Treaty on the European Economic Area, 1992, in force since January 1, 1994 